\title{
BAKTERI M2 PENGHASIL PHB (Polyhydroxybutirate) YANG DIISOLASI DARI PULAU LAKI, KEPULAUAN SERIBU
}

\author{
Dyah Supriyati \\ Peneliti Bidang Mikrobiologi, Pusat Penelitian Biologi-LIPI, Cibinong Life Science Center \\ JI. Raya Jakarta-Bogor km 46, Cibinong 16911, Bogor Telp. 021-8765066

\begin{abstract}
Polyhydroxybutirate Producing Bacteria M2 Isolated From Pulau Laki, Kepulauan Seribu. PHB is one of very important material for production of biodegradable plastic, and physiologically it is important electron sink in anaerobic-aerobic process. PHB accumulating bacteria $\mathrm{M} 2$ was isolated from mangrove of Pulau Laki, Kepulauan Seribu. The bacteria were able to produce PHB from glucose, acetate, and sucrose .Strain M2 was produced PHB (79.9\% of biomass) by using acetate as sole carbon sources. The strain was also able to grow at $3 \%$ to $5 \%$ with a doubling time of 10.9 and 21.04 hours and specific growth rate $\left(0.0633 \mathrm{~h}^{-1}\right.$ and $\left.0.0328 \mathrm{~h}^{-1}\right)$. The ability of Strain M2 to produce $P H B$ and its salinity tolerance implying that this strain is not only importance for PHB production but also ecologically importance microbe.
\end{abstract}

Key word: PHB accumulating bacteria, marine, salinity tolerance

\section{PENDAHULUAN}

Akibat menumpuknya limbah plastik, dan meningkatnya kesadaran masyarakat tentang perlunya pembuatan plastik yang mudah terurai oleh mikroba, memacu penelitian ekplorasi mikroba yang mampu menghasilkan jenis plastik yang mudah terurai seperti PHB (Polyhydroxybutirate). Di negara maju telah mulai diproduksi jenis plastik yang mudah dirombak secara biologis, yang dihasilkan oleh berbagai macam bakteri. PHB, merupakan bahan plastik tahan panas yang ramah lingkungan,dan mempunyai nilai komersial yang tinggi (Young et.al., 1994). Beberapa mikroba yang dilaporkan bisa menghasilkan PHB adalah Alcaligenes eutrophus, Bacillus megaterium, Pseudomanas oleovorans, Rhodospirillum rubrum, Zogloea ramigera (Beaulieu et al.1995). Pada beberapa bakteri PHB merupakan cadangan energi, dann dapat mencapai $90 \%$ dari berat kering sel (Handrick,et.al. 2004). Dengan sumber karbon glukosa Azotobacter chroococcum dapat mengakumulasi $40 \%$ PHB (Quagliano \& Miyazaki, 1999). Menurut Madison dan Huisman (1999) bakteri dapat mengakumulasi PHAs sampai $90 \%$ dari berat kering selnya. Untuk mendapatkan diversitas jenis dan fisiologi mikroba yang mempunyai kemampuan tinggi dalam mensistesis PHB, maka perlu dilakukan ekplorasi mikrobia di berbagai jenis ekosistem. Ekosistem laut merupakan sumber genetika yang tidak terbatas, yang belum banyak dipelajari dan dilaporkan tentang kemampuan mikroba laut dalam menghasilkan PHB. Sedangkan air laut merupakan salah satu media yang dapat dikembangkan untuk menumbuhkan mikrobia potensial terutama mikroba penghasil PHB. Karakteristik ekologi dan fisiologi (terutama penggunaan sumber $\mathrm{C}$ dan aktivitas enzimatik) dapat digunakan 
untuk memprediksi distribusi ekologi dari jasad renik tersebut.

Pada akhirnya penelitian ini ingin mengungkapkan kemampuan mikrobia laut yang terkait dengan potensinya sebagai penghasil PHB. Informasi yang didapat juga dapat dijadikan sebagai acuan keragaman mikrobia daerah tropika.

\section{METODOLOGI}

\subsection{Media air laut}

Media yang digunakan untuk menginkubasi sampel adalah media air laut dengan sumber Karbón yang terdiri dari Glukosa , Sucrosa atau Na Asetat masingmasing $1.7 \mathrm{gram} / \mathrm{l}$, Yeast Extract $0.5 \mathrm{gram} / \mathrm{l}$. Untuk Isolasi dan pemurnian isolate dibuat media air laut padat, dengan menambahkan 22 gram agar.

\subsection{Pengambilan Sampel}

Sampel diambil dengan menggunakan botol sample pada lokasi : S.05 5735.8 E.106 31 12.6. Segera setelah diambil , masukan $200 \mu \mathrm{l}$ sample ke dalam $5 \mathrm{ml}$ media air laut yang sudah steril di dalam test tube. Inkubasi di atas shaker pada suhu kamar selama 2 hari. $50 \mu \mathrm{l}$ sample di tanam merata di dalam media air laut padat dengan menggunakan spatula. Isolat yang muncul diambil dan dimurnikan.

\subsection{Uji Pertumbuhan isolat M2 pada media air laut}

\section{Variasi sumber karbon}

Isolat bakteri yang telah murni, ditumbuhkan pada media air laut dengan sumber karbon masing-masing sukrosa, glukosa atau $\mathrm{Na}$ asetat sebanyak $5 \mathrm{~g} / \mathrm{l}$.. Inkubasi di atas shaker pada suhu kamar. Pertumbuhan diamati setiap 4 jam. dengan spektrofotometer pada panjang gelombang $600 \mathrm{~nm}$

\section{Variasi salinitas}

Bakteri ditumbuhkan pada media air laut dengan sumber karbon campuran sukrosa glukosa dan Na.asetat dengan salinitas 3\% dan 5\% Inkubasi di atas shaker pada suhu kamar. Pengamatan dilakukan setiap 4 jam, dengan spektrofotometer pada panjang gelombang $600 \mathrm{~nm}$.

\section{Variasi $\mathrm{pH}$}

Bakteri ditumbuhkan pada media air laut dengan sumber karbon campuran sukrosa glukosa dan Na.asetat dengan salinitas pH 8 dan 5 Inkubasi di atas shaker pada suhu kamar. Pengamatan dilakukan setiap 4 jam, dengan spektrofotometer pada panjang gelombang $600 \mathrm{~nm}$.

\subsection{Biomassa}

Biomassa sel dihitung dengan cara menimbang berat sel yang ada pada $1 \mathrm{ml}$ kultur sampel. $1 \mathrm{ml}$ kultur sampel disentrifus pada 5000 rpm selama 20 menit , pada $4^{\circ} \mathrm{C}$. Buang supernatant. Keringkan dengan incubator suhu $60^{\circ} \mathrm{C}$ selama 24 jam, kemudian ditimbang beratnya.

\subsection{Produksi PHB}

Pengujian produksi PHB oleh isolat bakteri dilakukan dengan metode pewarnaan dengan pewarna Suddan Black. Pewarna Suddan black dibuat dengan mencampurkan $60 \mathrm{mg}$ Suddan Black ke dalam $200 \mathrm{ml}$ etanol $70 \%$. Larutan di campur sampai rata dengan stirrer, kemudian di inkubasi selama 1 malam (Arson, 1990 dan Crookham \& Dapson 1991).

$0.75 \mathrm{ml}$ sampel kultur dicampur dengan $0.75 \mathrm{ml}$ pewarna Suddan Black di dalam appendorf, menggunakan vortex selama 1 menit. Inkubasi selama 1 jam pada suhu kamar. Amati dengan spektrofotometer pada panjang gelombang $595 \mathrm{~nm}$. Sampel kemudian disentrifus selama 10 menit, dengan kecepatan $5000 \mathrm{rpm}$, suhu $4^{\circ} \mathrm{C}$. Supernatan kembali diamati dengan 
spektrofotometer dengan panjang gelombang 595 nm (Gambar 1)

Produksi PHB dihitung dengan mengurangi hasil pengamatan dengan spektrofotometer panjang gelombang 595 $\mathrm{nm}$ sampel sebelum dan sesudah disentrifus. Hasil pengurangan kemudian dihitung dengan standar antara konsentrasi PHB yang diperlakukan sama seperti sampel, yang diukur dengan spektrofotometer pada panjang gelombang $595 \mathrm{~nm}$. Hubungan antara konsentrasi PHB dengan OD pada panjang gelombang $595 \mathrm{~nm}$ tercantum dalam persamaan $\mathrm{Y}=4.1749 \mathrm{x}+0.1364 \mathrm{R}^{2}$ $=0.9701$ (Gambar 2)

Dengan melakukan pendekatan konversi nilai kekeruhan optis (OD) menjadi nilai $\mathrm{N}$ atau jumlah sel per volume medium (sel/mL), dapat dihitung pertumbuhan bakteri per jam atau nilai laju pertumbuhan spesifik $(\mu)$ dan juga waktu generasi atau doubling time $\left(\mathrm{t}_{\mathrm{d}}\right)$ yaitu waktu yang dibutuhkan oleh induk sel untuk membentuk sel baru (Baranyi \& Pin, 1999).

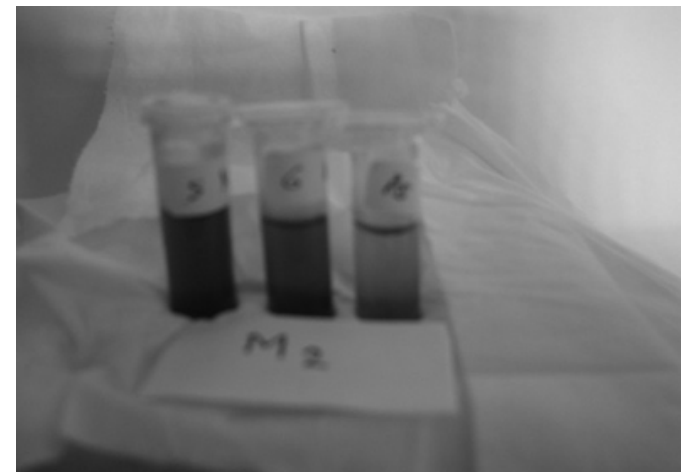

Gambar 1. Sel bakteri yang mengandung PHB pada media dengan sumber karbon Sukrosa (S), Glukosa (G) dan Na.Asetat (AS) menyerap pewarna Suddan Black.

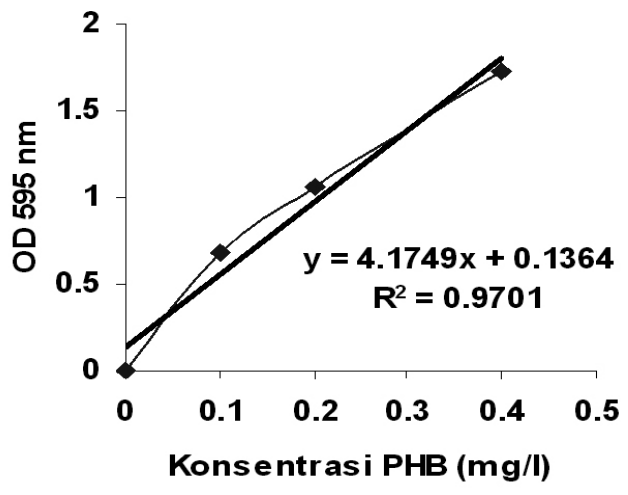

Gambar 2. Korelasi antara konsentrasi PHB dengan OD $595 \mathrm{~nm}$

\section{HASIL DAN PEMBAHASAN}

\subsection{HASIL}

Pertumbuhan bakteri M2 pada media air laut dengan sumber karbon yang berbeda.

\section{Variasi sumber karbon}

Penelitian ini bertujuan untuk mengetahui afinitas penggunaan substrat sukrosa, Na-asetat dan glukosa oleh Isolat M2. Pada semua perlakuan M2 sudah mulai tumbuh setelah 4 jam inkubas, mengindikasikan bahwa strain ini mampu dengan mudah menggunakan ke-tiga sumber karbon tersebut. Di akhir percobaan pertumbuhan tertinggi dicapai pada media dengan sumber karbon Na-asetat. Kemudian diikuti oleh sukrosa dan glukosa. Pada 24 jam pertama pertumbuhan Isolat M2 pada media dengan sumber karbon glukosa yang tertinggi. Saat 96 jam setelah inkubasi isolat M2 yang ditumbuhkan pada media dengan sumber karbon Sukrosa dan $\mathrm{Na}$ asetat belum turun pertumbuhannya, sedang yang ditumbuhkan pada media dengan sumber karbon glukosa sudah turun (Gambar 3). Hal tersebut mengungkapkan bahwa metabolisma untuk biokonversi substrat menjadi biomassa berbeda untuk asam asetat, glukosa dan sukrosa 


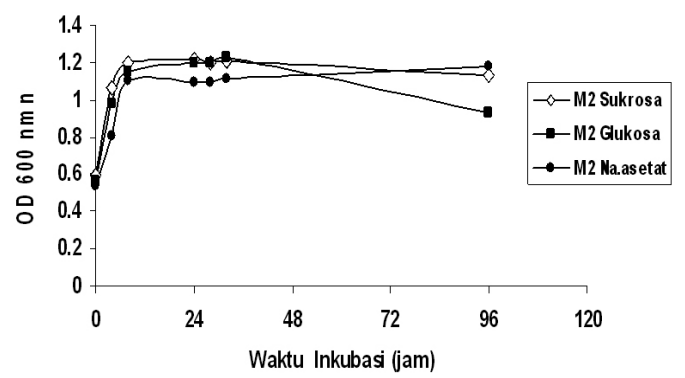

Gambar 3. Pertumbuhan bakteri M2 pada media air laut dengan sumber karbon berbeda

Pola pertumbuhan dan rentang salinitas

Penelitian ini bertujuan untuk mengetahui kemampuan tumbuh dan adaptasi isolat M2 pada salinitas $3 \%$ dan 5 $\%$, Ketiga sumber karbon dapat digunakan dengan baik oleh isolat M2 (Gambar 3). Pada kedua salinitas, isolat dapat tumbuh dengan baik pada awalnya.

Namun setelah 24 jam, konsentrasi $\mathrm{NaCl}$ $5 \%$ menghambat pertumbuhan isolat M2 (Gambar 4). Pertumbuhan bakteri M2 pada media dengan sumber karbon campuran sukrosa, glukosa dan Na.asetat dengan salinitas 3\% lebih baik dibandingkan dengan pada salinitas $5 \%$. Hal ini mengindikasikan bahwa metabolisma isolat M2 masih normal pada konsentrasi $\mathrm{NaCl} 3 \%$

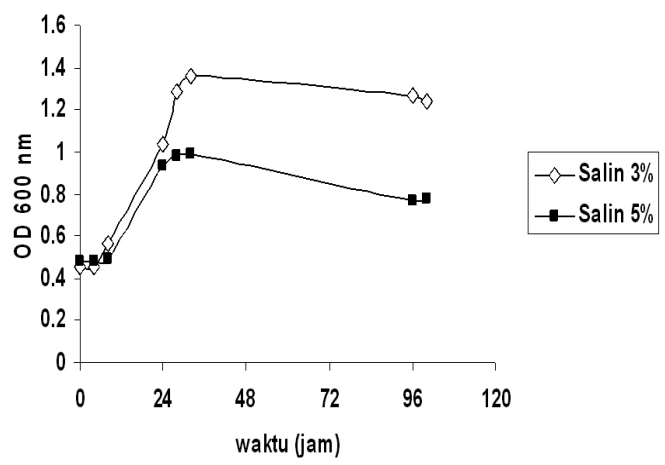

Gambar 4. Pertumbuhan bakteri M2 pada media dengan salinitas berbeda
Pertumbuhan bakteri M2 pada media dengan $\mathrm{pH} 8$ jauh lebih baik dibandingkan dengan pada $\mathrm{pH} 5$ (gambar 5), hal ini mengindikasikan bahwa metabolisma yang terkait dengan pertumbuhan sel terhambat pada $\mathrm{pH}$ 5. Distribusi ekologi dari isolat M2 dibatasi oleh $\mathrm{pH}$ lingkungan. Isolat ini akan mampu tumbuh baik pada $\mathrm{pH}$ netral atau sedikit basa.

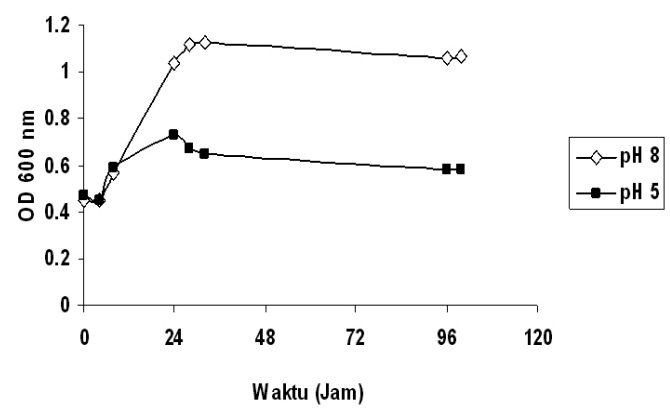

Gambar 4. Pertumbuhan bakteri M2 pada media dengan $\mathrm{pH}$ berbeda

\section{Biomassa}

Produksi sel terbanyak dicapai oleh bakteri M2 yang tumbuh pada media dengan sumber karbon sukrosa, kemudian Na.Asetat dan terkecil glukosa. (gambar 5)

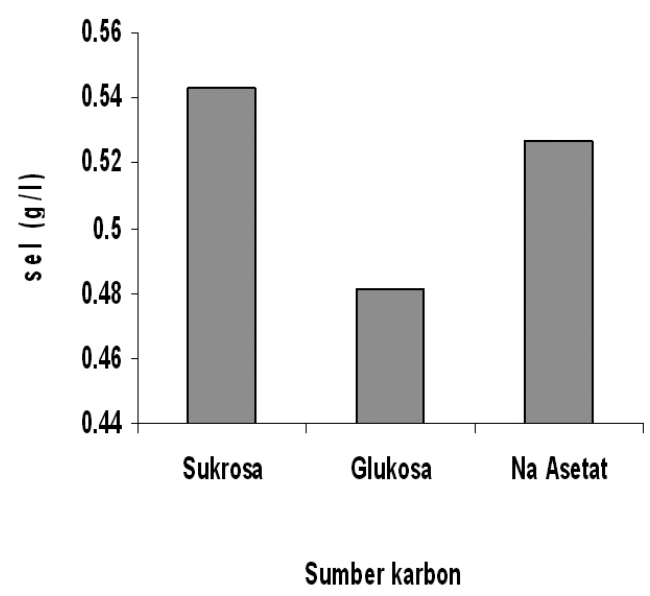

Gambar 5. Produksi sel pada media air laut dengan sumber karbon berbeda. 


\section{Produksi PHB}

Produksi PHB dihitung dengan jumlah $\mathrm{g} /$ liter kultur dan prosentase PHB dalam biomassa.. Produksi PHB tertinggi dicapai oleh bakteri M2 pada media dengan sumber karbon Na.asetat, kemudian diikuti glukosa dan sukrosa.masing-masing sebanyak $79.9 \%, 52.14$ dan $30.02 \%$ dari total biomassanya (gambar 6 dan 7)

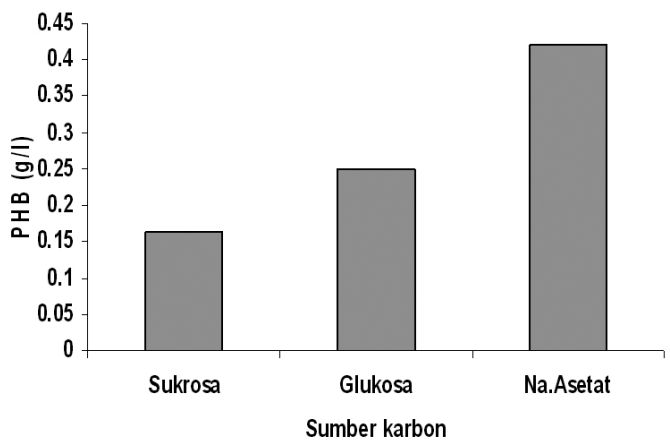

Gambar 6. Produksi PHB oleh bakteri M2 pada media dengan sumber karbon berbeda

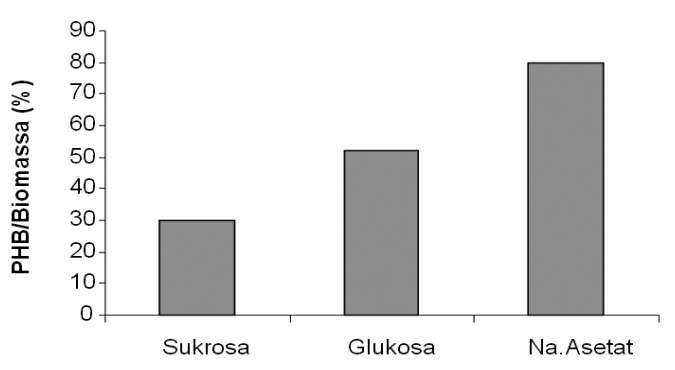

Sumber karbon

Gambar 7. Prosentase PHB dalam biomassa yang dihasilkan oleh bakteri M2 di dalam media dengan sumber karbon berbeda.

Dari hasil uji pertumbuhan pada media dengan sumber karbon campuran sukrosa, glukosa dan Na.asetat, dengan rentang salinitas dan $\mathrm{pH}$ terlihat bahwa bakteri M2 tumbuh lebih baik pada media dengan dengan sumber karbon tunggal sukrosa, glukosa atau Na.asetat . Pada uji pertumbuhan dengan salinitas dan $\mathrm{pH}$ berbeda tersebut, bakteri mempunyai waktu generasi $\left(t_{d}\right)$ yang lebih lama dibandingkan dengan $t_{d}$ pada media dengan sumber karbon tunggal.

Persamaan linear waktu dengan Ln N untuk penentuan nilai $\mu$ dan $t_{d}$ dari salinitas $3 \%$ dan $5 \%$ pada $\mathrm{M} 2$.

\subsection{PEMBAHASAN}

Uji Pertumbuhan. Pertumbuhan bakteri M2 pada media air laut dengan sumber karbon sukrosa, glukosa dan Na.Asetat. Artinya setiap 9 - 10 jam bakteri M2 terbentuk dua sel baru hasil pembelahan biner dari sel induk bakteri M2. Waktu generasi tercepat dicapai oleh bakteri M2 yang tumbuh pada media dengan sumber karbon Sukrosa.

Sukrosa akan digunakan oleh sel untuk pembentukan biomassa melalui proses hidrolis oleh enzim invertase menjadi glukosa dan fruktosa, selanjutnya kedua substrat tersebut melalui proses glikolisis menjadi asam piruvat dan melallui siklus Kreb akan menghasilkan produk antara yang dapat mengarah ke pembentukan protein dan senyawa lipida yang diperlukan untuk pertumbuhan sel. Hasil pembentukan biomassa mengindikasikan bahwa konversi sukrosa menghasilkan biomassa paling tinggi, dibandingkan dengan sumber karbon yang lain.

Persamaan linear waktu dengan Ln $\mathbf{N}$ untuk penentuan nilai $\mu$ dan $t_{d}$ dari sumber karbon sukrosa, glukosa dan $\mathrm{Na}$.Asetat pada M2.

\begin{tabular}{|l|l|c|c|c|}
\hline $\begin{array}{c}\text { Sumber } \\
\text { karbon }\end{array}$ & $\begin{array}{c}\text { Persamaan } \\
\text { Linear } \\
\text { penentuan } \mu\end{array}$ & $\begin{array}{c}\mathrm{R}^{2} \\
\text { Persamaan } \\
\text { Linear }\end{array}$ & $\mu\left(\right.$ jam $\left.^{-1}\right)$ & $\begin{array}{c}\mathrm{T}_{d} \\
(\text { jam })\end{array}$ \\
\hline Sukrosa & $\begin{array}{l}\mathrm{Y}=0.076 \mathrm{x} \\
+0.6463\end{array}$ & $\mathrm{R}^{2}=0.9066$ & 0.076 & 9.08 \\
\hline Glukosa & $\begin{array}{l}\mathrm{Y}=0.0724 \mathrm{x} \\
+0.6108\end{array}$ & $\mathrm{R}^{2}=0.9437$ & 0.0724 & 9.53 \\
\hline Na.Asetat & $\mathrm{Y}=0.0709$ & $\mathrm{R}^{2}=0.9992$ & 0.0709 & 9.86 \\
\hline
\end{tabular}

Ket: nilai $t_{d}=(\operatorname{Ln} 2 / \mu)$ 


\begin{tabular}{|l|l|c|c|c|}
\hline Salinitas & $\begin{array}{l}\text { Persamaan } \\
\text { Linear } \\
\text { penentuan } \mu\end{array}$ & $\begin{array}{c}\mathbf{R}^{2} \\
\text { Persamaan } \\
\text { Linear }\end{array}$ & $\begin{array}{c}\mu \\
\left(\text { jam }^{-1}\right)\end{array}$ & $\begin{array}{c}\mathbf{T}_{d} \\
\left(\mathbf{j a m}^{\prime}\right)\end{array}$ \\
\hline $\begin{array}{l}\text { Salinitas } \\
3 \%\end{array}$ & $\begin{array}{l}\mathrm{Y}=0.0633 \mathrm{x} \\
+0.5147\end{array}$ & $\mathrm{R}^{2}=0.8361$ & 0.0633 & 10.9 \\
\hline $\begin{array}{l}\text { Salinitas } \\
5 \%\end{array}$ & $\begin{array}{l}\mathrm{Y}=0.0328 \mathrm{x} \\
+0.4807\end{array}$ & $\mathrm{R}^{2}=0.978$ & 0.0328 & 21.04 \\
\hline
\end{tabular}

Waktu generasi isolat M2 yang lebih lama pada media dengan salinitas 5\% dengan td 21.04 jam dan laju pertumbuhan 0.0328 jam-1), menunjukkan bahwa bakteri tersebut terhambat pertumbuhannya.Pada media dengan salinitas $3 \%$ pertumbuhan bakteri M2 jauh lebih baik dengan waktu generasi (10.9 jam) dan laju pertumbuhan 0.0633 jam $^{-1}$

Persamaan linear waktu dengan Ln N untuk penentuan nilai $\mu$ dan $\mathrm{t}_{\mathrm{d}}$ dari $\mathrm{pH} 8$ dan $\mathrm{pH} 5$ pada M2

\begin{tabular}{|l|l|l|l|l|}
\hline pH & $\begin{array}{l}\text { Persamaan } \\
\text { Linear } \\
\text { penentuan } \mu\end{array}$ & $\begin{array}{l}\mathbf{R}^{2} \\
\text { Persamaan } \\
\text { Linear }\end{array}$ & $\begin{array}{l}\mu \\
\text { (jam }{ }^{-1} \text { ) }\end{array}$ & $\begin{array}{l}\mathbf{T}_{d} \\
\text { (jam) }\end{array}$ \\
\hline pH 8 & $\begin{array}{l}\mathrm{Y}=0.0619 x \\
+0.4835\end{array}$ & $R^{2}=0.9999$ & 0.0619 & 11.15 \\
\hline pH 5 & $\begin{array}{l}\mathrm{Y}=0.0229 x \\
+0.4445\end{array}$ & $R^{2}=0.811$ & 0.0229 & 30.13 \\
\hline
\end{tabular}

Ket: nilai $t_{d}=(\operatorname{Ln} 2 / \mu)$

Begitu juga pertumbuhan bakteri M2 pada media dengan $\mathrm{pH} 5$, dengan waktu generasi 30.13 jam dan laju pertumbuhan 0.0229 jam $^{-1}$ menunjukkan bahwa bakteri terhambat pertumbuhannya . Pada media dengan $\mathrm{pH} 8$ bakteri tumbuh jauh lebih baik dengan waktu generasi 11.15 jam dan laju pertumbuhan 0.0619 jam $^{-1}$

\section{Produksi PHB}

Produksi PHB terbesar dicapai oleh mikroba M2 yang tumbuh pada media dengan sumber karbon Na.asetat $79.9 \%$ dari biomassa). Dengan sumber karbon sukrosa produksi PHB $30.02 \%$ dan dengan glukosa $52.14 \%$ dari biomassa. Hal ini terjadi karena untuk membentuk PHB ada 3 jenis ensim yang berperan yaitu ensim $\beta$ ketocyl CoA thiolase (PhbA), acetoacetylCoA reduktase $(\mathrm{PhbB})$ dan $\mathrm{P}(3 \mathrm{HB})$ polymerase (Madison dan Huisman, 1999; Anderson \& Dawes, 1990). Acetyl Co A mudah diperoleh dengan adanya asetat di dalam media sebagai sumber karbon nya, bakteri dapat langsung menggunakan dan mensintesanya menjadi PHB. Produksi PHB dengan sumber karbon glukosa juga lebih banyak dibandingkan dengan sukrosa.Glukosa dapat digunakan langsung oleh bakteri menghasilkan energi untuk mensintesa PHB, sedangkan untuk menggunakan sukrosa bakteri harus memecahnya terlebih dahulu menjadi fruktosa dan glukosa.

\section{KESIMPULAN}

PHB diproduksi oleh Isolat M2 dengan menggunakan $\mathrm{Na}$-asetat, glukosa dan sukrosa. Sukrosa memacu pembentukan biomassa, sedangkan $\mathrm{Na}$-asetat memacu pembentukan $\mathrm{PHB}$. Isolat $\mathrm{M} 2$ dapat tumbuh baik pada salinitas $3 \%$, dan $\mathrm{PH} 8$, dan terhambat pada salinitas $5 \%$ dan $\mathrm{pH} 5$. Kemampuan memproduksi PHB terbanyak yaitu $79.9 \%$ dari total biomassa dicapai oleh bakteri M2 yang tumbuh pada media dengan sumber karbon Na.asetat.

\section{Ucapan Terima Kasih}

Ucapan terima kasih penulis sampaikan kepada Dr. Made Sudiana yang telah membantu selama penelitian dan penulisan makalah ini

\section{DAFTAR PUSTAKA}

1. Anderson, A.J. and E.A. Dawes. 1990. Occurence, metablolism, metabolic role and industrial uses of bacterial polyhydroxyalkanoats. Microbiol.Rev. $54: 450-472$.

2. Arson, F. 1990. Histotechnology. A Self Instructional Test. 1st ed .p.161-162. ASCP Press 
3. Baranyi,J. \& C.Pin. 1999. Estimasi bacterial growth parameters by mean of detection time. Appl.Environ. Microbial $65: 732-736$.

4. Beaulieu,M., Y. Beaulieu, J.Melinard, S.Pandia dan J.Goulet.1995. Influence of Ammonium Salt and Cane Molasses on Growth of Alcaligenes eutrophus and Production of Polyhydroxybutyrate. Appl.Environ.Microbiology. 165 - 169. American Society for Microbiology.

5. Bergesen,F.J. and G.L.Turner. 1992. Supply of $\mathrm{O} 2$ regulates $\mathrm{O} 2$ demand during utilization of reverse of Poly $\beta$.hydroxybutirate in N2 fixing soy bean bacteroid. Proc.R.Soc. London Ser.B $249: 143-148$.

6. Crookham,J.And R. Dapson. Hazardous Chemical in the Histopathology laboratory, 2nd ed.1991.Anatech.

7. Madison,L.L., \& G.W. Huisman. 1999. Metabolic Engineering of Poly (3-Hydroxybutirate) from DNA to plastic. Microbiology Molecular Biology Reviews.Mar. 1999:21 - 53.

8. Quagliano, J.C.\& S.S. Miyazaki. 1999. Biosynthesis of Poly- $\beta$-hydroxybutirate and exopolysaccharides on Azotobacter chroococcum strain 6B utilizing simple and complex carbon source. Appl. Biochemistry and Biotechnology . 82 (3): 199-208.

9. Handrick,R.,S.Reindart, D.Schultheiss, T.Reichart, D.Schuler, V.Jendrossek and D.Jendrossek. 2004. Unravelling the function of the Rhodospirillum rubrum. Activator of Polyhydroxybutirate (PHB) Degradation: The activator is PHB granule-bound protein (Phasin). J.Bacteriology 186 (8) : 2466 - 2475.

10. Young,E.K., J.R. Kastner and S.W. May .1994. Microbial production of Poly $\beta$-hydroxybutirate Acid from D-Xylose and Lactose by Pseudomonas cepacia. Appl. And Environ. Microbi1ology. P. 4195 - 4198. American Society for Microbiology. 